\title{
Development of Social Media Online Education Communication Strategy in Jean Mayer Preschool
}

\author{
Jenni Florida Tambunan ${ }^{1}$, Rachmat Kriyantono², Bambang Dwi Prasetyo ${ }^{3}$ \\ ${ }^{1,2,3}$ Department of Communication, Faculty of Social and Political Sciences, \\ University of Brawijaya, Malang, Indonesia \\ Email: jeanietambunan0106@yahoo.com
}

\begin{abstract}
Since the end of 2019, the dynamics of global life have been shaken by the Covid-19 pandemic. The Covid-19 pandemic has also caused multi-sectoral impacts on various areas of human life, one of which has an impact on the field of education. This study aims to determine the marketing communication strategy carried out by Jean Mayer Preschool to continue to exist in the pandemic era. This research is a type of qualitative research. The focus of this research is to find out the educational services promotion strategy at Jean Mayer Preschool. The data collection technique in this research is interview. Data analysis technique is through Miles, Huberman, Saldana. The results showed that the marketing strategy for educational services after the pandemic during the distance education (PJJ) was to use social media for the promotion of montessori activities and English language habituation. The method used is Home Based Learning, Video Watching Learning, Home Visit Learning. The social media used are Facebook, Instagram, and WhatsApp. The digital marketing strategies used include selecting photos, videos, and writing captions to promote Jean Mayer preschool. Social media is used effectively as the actualization of digital marketing in order to maintain communication and improve the quality of distance learning (PJJ) between teachers, students and parents of students.
\end{abstract}

Keywords: Marketing, Promotions, Social Media, Digital Marketing.

\section{A. INTRODUCTION}

Since the end of 2019, the dynamics of global life have been shaken by the Covid-19 pandemic, which is contagious in a very fast time, covers a very wide area, and this pandemic has forced people to continue to stay indoors, while still applying physical and social distancing (Juliantari, 2020). The Covid-19 pandemic has also caused multi-sectoral impacts on various areas of human life and can be categorized as a crisis. Crisis is an unexpected situation that creates instability and uncertainty and sometimes leading to rising panic (Kriyantono \& Mc Kenna, 2019). Not only causing health problems, the Covid-19 pandemic also has an impact on the fields of education, socio-communication, socio-economy and religious practices (Rothan \& Byrareddy, 2020).

In the education sector in Indonesia, the Minister of Education and Culture (Mendikbud) Nadiem Anwar Makarim issued Circular Number 4 of 2020 concerning the Implementation of Education in an Emergency for Coronavirus Disease (Covid19) as an educational policy that must be considered and implemented by school principals, teachers, students, and all parties related to educational activities at school. The actualization of this policy can be seen in various forms of activities such as online 
learning from home, webbinars, changes to the examination assessment mechanism as well as the registration, selection and acceptance process for new students.

Jean Mayer Preschool is one of the early childhood education institutions in Jayapura City, Papua. The reason the researchers chose Jean mayer preschool as the object of research is because Jean mayer preschool is the first school to implement the Montessori education system in Jayapura. Adoption of the Montessori theory in the learning process emphasizes the importance of efforts to build independence, natural learning, curiosity, freedom of choice, making decisions, cooperation, sustainability, balance of all aspects of children's education, order and problem solving in children's education. In other words, the educational system developed by Jean Mayer Preschool is child-centered creative learning. Teachers are only facilitators who will help students to do and find things based on their own abilities and ways. This is intended to develop the potential of students' children optimally. In addition, Jean Mayer preschool is the only PAUD in Jayapura that uses English as the language of instruction in Jayapura.

The conditions during the Covid-19 pandemic as mentioned above also influenced the way educational institutions carried out marketing communications for educational services. As an educational institution, Jean Mayer preschool is also challenged to make relevant adaptations in responding to existing conditions and striving to achieve the goals and targets of the institution. In the face of the existing Covid-19 pandemic conditions, Jean Mayer preschool is required to find and develop other alternatives to continue to be able to carry out marketing communications for educational services. One alternative that needs attention is the careful, effective and efficient use of internet services and activities in virtual spaces as a tactic to get around the situation and achieve the expected targets. In other words, preschool Jean Mayer needs to pay serious attention. Public relations practice has entered the known internet era as online public relations, public relations on the net, or digital public relations (Kriyantono, 2020). For this topic, Jean Mayer Preschool need to explore the way PR do develop communication strategy for online education service.

Before the Covid 19 pandemic, Jean Mayer preschool often held bazaars and promotions offline through various educational activities. However, seeing the conditions of the Covid 19 pandemic, Jean Mayer preschool developed a new marketing strategy through online media. On the one hand, the Covid 19 pandemic has had a negative impact on the economy and also difficulties in the field of education. Students and teachers are forced to undergo online communication and only undertake distance learning. This also has an impact on the lack of students who are interested in joining the Jean Mayer Preschool, one reason is because parents feel more secure when their children are at home and the need for school for early childhood is not as urgent as other levels of education.

On the other hand, several studies related to educational communication strategies in the pandemic era provided optimism for Jean Mayer preschool to stay afloat and rely on online communication strategies. This is evidenced by the success of research by Almaida \& Nugrahani (2019) which has proven that digital marketing 
strategies can help educational marketing strategies. Yopi \& Wahid (2020) who use a website management strategy and social media can attract brand equity to attract potential consumers of educational services. As well, Sumiyati \& Nurkhosi'in explained the importance of good relations among educational institutions' stakeholders to make good strategies.

This study seeks to determine the marketing communication strategy carried out by Jean Mayer Preschool to continue to exist in the pandemic era. The main difference between these studies and this study lies in the analysis used. In this study, researchers focused on finding out how social marketing was carried out by Jean Mayer preschool, which will propose the development of an online educational services marketing communication strategy in the future. This is done by promoting education services according to the process and competence of graduates, as well as improving students' ability to speak English. Furthermore, the promotion also emphasizes the promotion of social marketing by displaying the standards of education personnel including facilities and infrastructure delivered through social media and have a good relations to parents also another stakeholders. The organization should be positive in its attitude towards the public, including competitors and pressure groups regardless of whether they are supportive of or opposed to the organisation. They must be perceived as friends and partners. Harmony in the system happens if the elements of the system help and support in togetherness (Kriyantono \& McKenna, 2017)

This study aims to find out how the online educational services marketing communication carried out by Jean Mayer preschool during the Covid-19 pandemic. Communication strategy in normal and crisis situations should be pay attention to the public interest in order the public is not the party with the most suffer the consequences of the crisis (Kriyantono, 2015a; Kriyantono et al., 2017), as well as to analyze Miles, Huberman, \& Saldana (2014) to then offer the development of better online educational services marketing strategies in the future.

\section{B. LITERATURE REVIEW}

Marketing communication is a process of continuous dialogue between buyers and sellers in a marketing place. Through marketing communication there is a twoway exchange of information between parties or institutions involved in marketing activities (Bulaeng, 2002). In marketing communication, there are communication activities between buyers and sellers that help the decision-making process in the marketing sector and direct better exchange actions for both parties (Sutisna, 2002).

Conceptually, the marketing communication strategy covers the four main marketing areas and activities. First, product, which involves exploring the needs and interests of consumers as well as selecting the right goods and services offered. Second, price, namely the determination of the selling price by considering product quality and consumer affordability. Third, place, which is the selection of the place and way of distributing the product so that it can reach consumers appropriately. Fourth, promotion, namely the selection of the right promotion policy, in accordance 
with the products offered and the conditions that affect the affordability of consumers. In practice, the four elements do not stand alone, but are collaborated according to consumer needs and taking into account the relevant conditions. In this study, researchers focused on the way Jean Mayer preschool promoted educational services.

Coviello, Milley \& Marcolin (2001) explain that digital marketing is the use of Internet networks accompanied by the use of interactive technology that can connect two-way communication between companies and consumers. Digital marketing makes sales promotion easier so that many companies are now more sophisticated in marketing their products. In this pandemic era, Jean Mayer preschool focuses on doing a digital marketing process to market educational services that focus on montesori activities and strengthening English. Digital marketing provides broad opportunities for brand equity formation activities to become a strong brand and stick in the minds of the public or consumers at large. Thus, digital marketing can be understood as a marketing activity including branding that uses various web-based media such as blogs, websites, e-mail, adwords, or social media networks (Sanjaya \& Tarigan, 2009).

\section{METHODS}

This research is a type of qualitative research. Qualitative research is research that is used to understand the phenomenon of what the subject is experiencing in a holistic and descriptive manner (Moleong, 2011). Adopting Wimmer and Dominick (2011), the interview was chosen because the researcher intends to collect a life-world description of the interviewee in detail for the interpretation of meanings. This study aims to find out how the online educational services marketing communication carried out by Jean Mayer preschool during the Covid-19 pandemic, as well as to analyze Miles, Huberman, \& Saldana (2014) to then offer the development of better online educational services marketing strategies in the future.

The focus of the research is to find out the marketing communication strategy of online education services during the Covid-19 pandemic at the Jean Mayer preschool. Sources of data used in this study are the results of interviews. Data collection techniques used online interviews using the zoom application and google form for parents. Data triangulation was carried out by distributing Google Forms to parents.

\section{RESULTS AND DISCUSSION}

Based on the results of interviews with informants, it is known that the educational service marketing strategy that is prioritized by Jean Mayer Preschool in the pandemic era is to maximize the role of social media to support distance education (PJJ) activities. Marketing activities or marketing of educational services, which were previously considered "taboo" because they are business-oriented and tend to be profit-oriented, are now being carried out openly and openly (Fajri, 2019). This is done by implementing a marketing strategy focused on Montessori activities and strengthening English. 
The important role of a marketing communication strategy in a company is to trigger the sale of a product that the company produces, so that consumers know about the product. Marketing always tries to improve the quality of the relationship between the company and its consumers so that consumer awareness of the products or services offered by the company is known through the planning process in promotion. In this study, Jean Mayer preschool seeks to build good relationships with parents as an effort to provide education services by carrying out various activities, such as: greeting parents WhatsApp groups, holding parents teacher conferences, and always tagging or mentioning student activities through instastory so that there is a strong relationship between the two parties.

Jean Mayer preschool's educational services marketing strategy in the pandemic era is to use social media. The types of social media used by Jean Mayer preschool during HBL (Home Based Learning), VWL (Video Watching Learning), and HVL (Home Visit Learning) activities are Instagram, website, WhatsApp and Facebook. The use of social media during the PJJ (distance learning) period for PAUD students, is used by teachers in providing information related to learning materials that must be provided, reporting student assignments by parents of students, etc. Technically for its use in the field, classroom teachers must form groups on social media (WhatsApp groups) consisting of class teachers and all parents of students. Furthermore, all activities are published on Instagram, and Facebook.

Coviello, Milley \& Marcolin (2001) explain that digital marketing is the use of Internet networks accompanied by the use of interactive technology that can connect two-way communication between companies and consumers. Digital marketing makes sales promotion easier so that many companies are now more sophisticated in marketing their products. In this pandemic era, Jean Mayer preschool focuses on doing a digital marketing process to market educational services that focus on montessori activities and strengthening English.

Based on the results of a survey conducted by the Statista Research Department on August 13, 2020, the use of social networking media in Indonesia in 2020 was recorded at around 199.16 million and it is predicted that it will continue to increase in the following years. Social media has changed the culture of all levels of Indonesian society.

Some of the benefits of social media used by Jean Mayer Preschool in relation to education and learning at home, namely (1) facilitate interaction and communication between teachers and students, (2) provide learning materials. Here teachers can take advantage of social media and messaging applications to provide learning material as we are doing today by using Whatsapp groups, Zoom, Google Form, (3) helping to identify additional content (as learning resources) to strengthen or expand learning materials. and (4) social media is used as a means of publishing the results of online teaching and learning activities 


\section{E. CONCLUSION}

The marketing strategy for educational services after the pandemic during the Distance Education (PJJ) period is to use social media for the promotion of montessori activities and English language habituation. The method used is Home Based Learning, Video Watching Learning, Home Visit Learning. The social media used are Facebook, Instagram, and WhatsApp. The digital marketing strategies used include selecting photos, videos, and writing captions to promote Jean Mayer preschool. Social media is used effectively as the actualization of digital marketing in order to maintain communication and improve the quality of distance learning (PJJ) between teachers, students and parents of students.

\section{REFERENCES}

1. Coviello, N. Milley, R. \& Marcolin, B. (2001). Understanding it-enable interactivity in contemporary marketing. Journal of Interactive Marketing, 15 (4), 18-33.

2. Juliantri, N. K. (2020). Verbal and Nonverbal Communication Creativity in the New Normal Era. Jayapangus Press Books, 263-274.

3. Kriyantono, R. (2015). Public Relations, Issues, E Crisis Management: Pendekatan Critical Public Relations, Etnografi Kritis \& Kualitatif. Jakarta: Prenada.

4. Kriyantono, R. (2015). Konstruksi Humas Dalam Tata Kelola Komunikasi Lembaga Pendidikan Tinggi di Era Keterbukaan Informasi Publik. Jurnal Pekommas, 18(2), 117-126

5. Kriyantono, R. (2015a). Public relations, issue E crisis management: Pendekatan critical public relations, etnografi kritis $\mathcal{E}$ kualitatif. Jakarta: Kencana.

6. Kriyantono, R., Yuyun A. R., \& Savitri, R. I. (2017). Public's Attribution Vs Punitive Behavior in Indonesian Public Relations Practice. Jurnal Ilmu Komunikasi, 14(1), 4360 .

7. Kriyantono, R. (2017). Teori Public Relations Perspektif Barat \& Lokal: Aplikasi Penelitian dan Praktik. Jakarta: Kencana Prenada.

8. Kriyantono, R., \& McKenna, B. (2017). Developing a Culturally-Relevant Public Relations Theory for Indonesia. Malaysian Journal of Communication, 33(1).

9. Kriyantono, R., \& McKenna, B. (2019). Crisis response vs crisis cluster: A test of situational crisis communication theory on crisis with two crisis clusters in Indonesian Public Relations. Malaysian Journal of Communication, 35(1).

10. Kriyantono, R. (2020). Efektivitas Website Perguruan Tinggi Negeri Sebagai Penyedia Informasi Bagi Mahasiswa. Jurnal Studi Komunikasi, 4(1), 117-142.

11. Prisgunanto, I. (2006). Komunikasi pemasaran: Strategi dan taktik. 82-87.

12. Rothan, H. A., \& Byrareddy, S. N. (2020). The epidemiology and pathogenesis of coronavirus disease (COVID-19) outbreak. Journal of Autoimmunity, 102433.

13. Susilo, D. A., \& Yulianti, D. T. (2020). Implementasi Digital Marketing dan Analisis pada Sekolah Pelangi Harapan Bangsa Bandung. Jurnal Strategi-Jurnal Maranatha, 2(2), 388-396. 
14. Triana, N., \& Fachrury, R. (2019). Pengaruh Promosi Melalui Media Sosial Terhadap Keputusan Pembelian Dalam Viral Marketing di CV Seragam Sekolah Bhinneka Karawang. CIEHIS Prosiding, 1(1), 108-117.

15. Wimmer, R. D., \& Dominick, J.R. (2011). Mass Media Research: An Introduction. Boston: Wadsworth.

16. Yopi, M. W., \& Azis, F. (2020). Digital Brand Equity Melalui Sosial Media. AGUNA: Jurnal Ilmu Komunikasi, 1, 87-106 